\section{Composted Chicken Manure as a Medium for the Production and Delivery of Trichoderma virens for Weed Control}

\author{
Farah MG Héraux, ${ }^{1}$ Steven G. Hallett, ${ }^{2}$ K.G. Ragothama, ${ }^{1}$ and \\ Stephen C. Weller ${ }^{1}$ \\ Purdue University, West Lafayette, IN 47907
}

Additional index words. biological control, bioherbicide, Viridiol, CCM, Trichoderma virens, integrated weed management

\begin{abstract}
Trichoderma virens (Gliocladium virens) (Miller et al.) von Arx is a soilborne fungus with a high degree of rhizosphere competence that produces a potent herbicidal compound, viridiol, and therefore has potential for development as a bioherbicide. We investigated the possibility of using composted chicken manure (CCM) as a medium for the production and deployment of $T$. virens. We chose CCM since the safe disposal of chicken manure presents significant logistic problems, and composted manures, as well as serving as an organic source of nitrogen, have been shown to support the activity of other biological control agents. Composted chicken manure supported the growth of $T$. virens and the rapid production of high concentrations of viridiol, but only when it was supplemented with large quantities of nutrients, including sucrose $(16 \% \mathrm{w} / \mathrm{w})$. Viridiol was not stable when stored in CCM, with a rapid decline in viridiol concentrations observed in $T$. virens-inoculated CCM cultures. Clearly, a cheaper alternative to sucrose is required as a carbon source for $T$. virens in CCM or similar media, and effective storage methods would need to be found for a $T$. virens-based bioherbicide product. Importantly, CCM did not need to be sterilized to support the growth of $T$. virens and its concomitant production of viridiol, suggesting that on-farm production systems may be feasible. Trichoderma virens-colonized CCM reduced the emergence and seedling growth of redroot pigweed (Amaranthus retroflexus L.) in a greenhouse experiment and dramatically reduced the emergence of a mixed community of broadleaf weeds in the field.
\end{abstract}

The development of bioherbicides has focused primarily upon the development of propagules of fungal plant pathogens for deployment as foliar sprays (Boyette et al., 1996). Some success has been achieved with this approach, and the field has been recently reviewed by Charudattan (2001) and Hallett (2005). More recently, the role of soilborne bacteria in weed suppression has been well established (Boyetchko, 1996; Cherrington and Elliott, 1987; Kremer and Kennedy, 1996; Kremer etal., 1990). Additionally, a wide range of soilborne fungi have been shown to have biocontrol potential, including Myrothecium verrucaria (Alb. and Schw.) Ditmar (Abbas et al., 2001; Anderson and Hallett, 2004; Boyette et al., 2002; Walker and Tilley, 1997), Fusarium spp. (Amsellem et al., 2001; Ciotola et al., 1996), Sclerotinia minor Jagger (Brière et al., 2000) and $T$. virens for the broad range suppression and control of weeds from a number of plant families (Howell and Stipanovic,

Received for publication 1 Dec. 2004. Accepted for publication 3 Mar. 2005. We acknowledge Jay Young, superintendent of Throckmorton Purdue Agricultural Center, and Dave Kent and Nina Kent, farmer cooperators. Research supported by SARE grant LWF 62-016-03608.

${ }^{1}$ Department of Horticulture and Landscape Architecture.

${ }^{2}$ Department of Botany and Plant Pathology. Author to whom correspondence should be addressed; e-mail halletts@purdue.edu.
1984; Hutchinson, 1999; Jones and Hancock, 1987; Jones et al., 1988).

Toxic secondary metabolites are commonly implicated in the biocontrol activity of soilborne microorganisms (Abbas and Duke, 1995; Alstrom and Burns, 1989; Bolton and Elliot, 1989; Sarwar and Kremer, 1995). Trichoderma spp. produce a range of toxic secondary metabolites, including gliovirin, gliotoxin, viridian and viridiol, of which viridiol is strongly phytotoxic (Jones and Hancock, 1987; Jones et al., 1988). Trichoderma spp. also possess a high level of rhizosphere competence (Harman, 1992).

Whereas the formulation of bioherbicides comprised of foliar pathogens has focused upon the enhancement of sprayability, leaf surface adhesion, spread and protection against desiccation (Boyette et al., 1996), the formulation of bioherbicides comprised of soilborne pathogens has focused upon the development of granular applications that support bioherbicide growth and efficacy (Brière et al., 2000; Ciotola et al., 1996; Daigle et al., 1997; Vogelgsang et al., 1998).

The development of a suitable technology for the mass production of the biocontrol agent is a requirement of all biocontrol systems (Charudattan, 2001; Hallett, 2005). Trichoderma virens has been produced in submerged culture (Eyal et al., 1997), on rice seeds (Howell and Stipanovic, 1984), nutrient-amended peatmoss (Jones and Hancock,
1987) and composted chicken manure (CCM) (Héraux, 1999; Hutchinson, 1999).

Composted chicken manure may have a number of benefits as a medium for the production and delivery of $T$. virens since it is an abundantly available renewable resource that can be obtained at low cost, and there is an urgent need for the development of cleaner methods for the disposal of poultry litter (Kelleher et al., 2002). Uninoculated chicken manure and composted chicken manure have been implicated in the suppression of plant diseases (Aryantha et al., 2000; Craft and Nelson, 199; Hoitink and Boehm, 1996; Hoitink and Fahy, 1986; Weller, 1988). The objectives of this study were to investigate the potential for the production of large quantities of $T$. virens on CCM, to test the production and stability of viridiol on CCM, and then to test the colonized mixture for weed control efficacy.

\section{Materials and Methods}

Maintenance of T. virens isolate and inoculation of composted chicken manure (CCM). Trichoderma virens was maintained on potato dextrose agar (PDA) and grown in a static liquid medium containing $10 \mathrm{~g}$ of glucose, $0.1 \mathrm{~g}$ of $\left(\mathrm{NH}_{4}\right)_{2} \mathrm{SO}_{4}, 1.0 \mathrm{~g}$ of $\mathrm{MgSO}_{4} \cdot 7 \mathrm{H}_{2} \mathrm{O}$, $0.5 \mathrm{~g}$ of $\mathrm{KH}_{2} \mathrm{PO}_{4}, 3 \mathrm{~mL} 1 \mathrm{~mm} \mathrm{Fe-EDTA} / \mathrm{L}$ (Hutchinson, 1999; Jones and Hancock, 1987). Composted chicken manure (CCM) (a mixture of manure and litter, including manure, straw and lost food; $1.3 \mathrm{~N}-1.7 \mathrm{P}-1.0 \mathrm{~K}$; Midwest Poultry Farms, Mentone, Ind.) was prepared by the addition of $1.0 \mathrm{~g}$ of $\left(\mathrm{NH}_{4}\right)_{2} \mathrm{SO}_{4}, 1.0 \mathrm{~g}$ of $\mathrm{MgSO}_{4} \cdot 7 \mathrm{H}_{2} \mathrm{O}, 2.0 \mathrm{~g}$ of $\mathrm{KH}_{2} \mathrm{PO}_{4}, 3 \mathrm{~mL} 3$ $\mathrm{mM} \mathrm{Fe}-E D T A$ and $200 \mathrm{~g}$ sucrose to $600 \mathrm{~mL}$ of CCM. Then, $30 \mathrm{~mL}$ of concentrated $\mathrm{HCl}$ was added and the CCM medium sterilizing by autoclaving $\left(121^{\circ} \mathrm{C}, 30 \mathrm{~min}\right)$. Composted chicken manure was inoculated with conidial suspensions of $T$. virens $\left(5 \times 10^{5}\right.$ conidia $/ g$ $\mathrm{CCM}$ ) and incubated at $25{ }^{\circ} \mathrm{C}$ in the dark, during which time, containers were gently shaken daily to ensure thorough mixing and colonization of the CCM by T. virens (Hutchinson, 1997).

Viridiol production by T. virens-inoculated $C C M$. Composted chicken manure was inoculated with conidial suspensions of $T$. virens and incubated as described above for $0,3,7,14,28$, or $35 \mathrm{~d}$. Viridiol was measured by absorbance at $317 \mathrm{~nm}$ in methanol following extraction in chloroform (Howell and Stipanovic, 1984). In a second experiment, CCM was prepared as described above, or with $1 / 2$ or $1 / 4$ concentrations of nutrient amendments, inoculated with conidial suspensions of $T$. virens, incubated for $7 \mathrm{~d}$, and viridiol concentrations measured as described above.

Concentration of viridiol after drying and storage of T. virens $+C C M$. Composted chicken manure was prepared and inoculated with $T$. virens as described above and then placed on the laboratory bench for $6 \mathrm{~d}$ to dry. After drying, viridiol concentration was measured as described above, either immediately (control), or after a further 14 or $28 \mathrm{~d}$ of storage.

Impact of $T$. virens $+C C M$ on growth of Amaranthus retroflexus L. seedlings in the 
Table 1. Viridiol production $\left(\mu \mathrm{g} \cdot \mathrm{mL}^{-1}\right)$ through time by Trichoderma virens in nutrient-supplemented CCM. Incubation at $25^{\circ} \mathrm{C}$ in the dark.

\begin{tabular}{lc}
\hline $\begin{array}{l}\text { Length of } \\
\text { incubation }(\mathrm{d})\end{array}$ & $\begin{array}{c}\text { Viridiol concn } \\
\left(\mu \mathrm{g} \cdot \mathrm{mL}^{-1}\right)\end{array}$ \\
\hline 0 & $0 \mathrm{a}^{\mathrm{z}}$ \\
3 & $0 \mathrm{a}$ \\
7 & $8.1 \mathrm{~b}$ \\
14 & $7.1 \mathrm{~b}$ \\
28 & $7.8 \mathrm{~b}$ \\
35 & $0 \mathrm{a}$ \\
\hline
\end{tabular}

${ }^{2}$ Mean separations by Tukey procedures; values with the same letter are not significantly different at $P \leq 0.05$.

Table 2. Viridiol production $\left(\mu \mathrm{g} \cdot \mathrm{mL}^{-1}\right)$ by Trichoderma virens in CCM supplemented with different concentrations of nutrients. Incubation at $25^{\circ} \mathrm{C}$ in the dark for $7 \mathrm{~d}$.

\begin{tabular}{lc}
\hline $\begin{array}{l}\text { Nutrient } \\
\text { concn }\end{array}$ & $\begin{array}{c}\text { Viridiol concn } \\
\left(\mu \mathrm{g} \cdot \mathrm{mL}^{-1}\right)\end{array}$ \\
\hline $\mathrm{X}^{z}$ & $12.9 \mathrm{a}^{\mathrm{y}}$ \\
$\mathrm{X} / 2$ & $11.9 \mathrm{a}$ \\
$\mathrm{X} / 4$ & $5.3 \mathrm{~b}$ \\
\hline${ }^{ } \mathrm{X}=1 \mathrm{~g}\left(\mathrm{NH}_{4}\right)_{2} \mathrm{SO}_{4}, 1 \mathrm{~g} \mathrm{MgSO}_{4}, 2 \mathrm{~g} \mathrm{KH}_{2} \mathrm{PO}_{4}, 3 \mathrm{~mL}$ \\
$\mathrm{Fe}-\mathrm{Na} \mathrm{EDTA}(3 \mathrm{mM}), 30 \mathrm{~mL} \mathrm{concentration} \mathrm{HCl}, 333^{\text {g sucrose } / \mathrm{kg} \mathrm{CCM} .}$ \\
y $\mathrm{Mean}$ separations by Tukey procedures; values \\
with the same letter are not significantly different \\
at $P \leq 0.05$.
\end{tabular}

greenhouse. Composted chicken manure was either prepared and inoculated with $T$. virens as described above (sterilized) or was prepared as described but not autoclaved before inoculation (unsterilized). Two hundred seeds of $A$. retroflexus were sown by mixing into the top $6 \mathrm{~mm}$ of a silt loam soil in seedling trays $(15 \times$ $10 \mathrm{~cm}$ ). In total, $60 \mathrm{~mL}$ of a CCM preparation was also mixed into the top $6 \mathrm{~mm}$ of soil: 1$)$ vermiculite (untreated), 2) uninoculated CCM, 3 ) sterilized CCM inoculated with $T$. virens stored for $14 \mathrm{~d}$ after drying, 4) unsterilized CCM inoculated with $T$. virens stored for 14 $\mathrm{d}$ after drying, 5) sterilized CCM inoculated with $T$. virens stored for $7 \mathrm{~d}$ after drying, and 6) unsterilized CCM inoculated with $T$. virens stored for $7 \mathrm{~d}$ after drying. Plants were watered as needed, and the number of emerged seedlings was recorded weekly. Aboveground plant parts were harvested 21 days after treatment by cutting at the soil surface, and dry biomass was measured after drying at $65^{\circ} \mathrm{C}$ for $3 \mathrm{~d}$.

Impact of T. virens + CCMapplications upon weed emergence in the field. Field experiments were performed at Brookston, Indiana in 1997 and 1998. Composted chicken manure or $T$. virens + CCM was prepared as described above. In 1997 CCM was incubated with T. virens for $28 \mathrm{~d}$, whereas in 1998, CCM was incubated with T. virens for $7 \mathrm{~d}$. Composted chicken manure or $T$. virens $+\mathrm{CCM}$ were spread by hand in the field at the rate of $15 \%$ volume:volume of the top $1.5 \mathrm{~cm}$ of soil and then raked into the soil to ensure uniformity of coverage within the plot. The herbicide Dual 8E [metolachlor; 2-chloro- $N$-(2-ethyl-6-methylphenyl)- $N$ (2-methoxy-1-methylethyl)acetamide] was applied to control plots on 6 Nov. 1997 and 28 May 1998. Fertilizer was applied to all plots in order to maintain equal levels of total nitrogen; organic fertilizer $(2.27 \mathrm{~kg} / \mathrm{plot}$;
8-4-4; Rose Acre Farms, Seymour, Ind.) was applied to plots receiving CCM; urea $(0.45$ $\mathrm{kg} / \mathrm{plot} ; 46-0-0$ ) was applied to control plots. The experimental design was a split plot, with four replicates. Plots were $9 \times 2 \mathrm{~m}$. Fields were prepared by chisel plow in the preceding fall and field cultivator each spring before planting, and snap beans (Phaseolus vulgaris L. 'Strike') were seeded as the test crop at a rate of $111 \mathrm{~kg} \cdot \mathrm{ha}^{-1}$ with a Great Plains no-till drill. Soil nutrient analyses (A and L Great Lakes Laboratory, Inc., Fort Wayne, Ind.) for the field immediately before planting were as follows: 1997: organic matter 1.6\%; P 67.5 ppm; K 212.8 ppm; Mg 260 ppm; Ca 837.5 ppm; pH 6.2, cation exchange capacity 8.0. 1998: organic matter $1.5 \%, \mathrm{P} 46.5 \mathrm{ppm}, \mathrm{K}$ 200.0 ppm, Mg 217.5 ppm, Ca 725 ppm, pH 7.1 , cation exchange capacity 7.8 , and soil was amended as needed to meet the requirements of a snap bean crop as recommended by ID 56, Midwest Vegetable Production Guide (Foster et al., 1998). Weeds were counted 7, 14, and 21 DAP with a $0.09-\mathrm{m}^{2}$ quadrat which was placed randomly four times in each plot, and the counts averaged. Aboveground plant parts were harvested 21 DAP by cutting at the soil surface and dry biomass measured following drying at $60^{\circ} \mathrm{C}$ for $3 \mathrm{~d}$.

Statistical analyses. All experiments were arranged in randomized complete blocks with five replications, and were repeated at least once. Data from repeated experiments were pooled following verification of homogeneity of variances (Gomez and Gomez, 1984). Experiments were each analyzed by analysis of variance (ANOVA) with the Statistical Analysis Software (SAS Inst., Cary, N.C.) with mean separations by Tukey's test at $P \leq 0.05$.

\section{Results}

Viridiol production by T. virens-inoculated $C C M$. The production of viridiol by $T$. virens incubated in nutrient-amended CCM changed through time, with concentrations highest be-

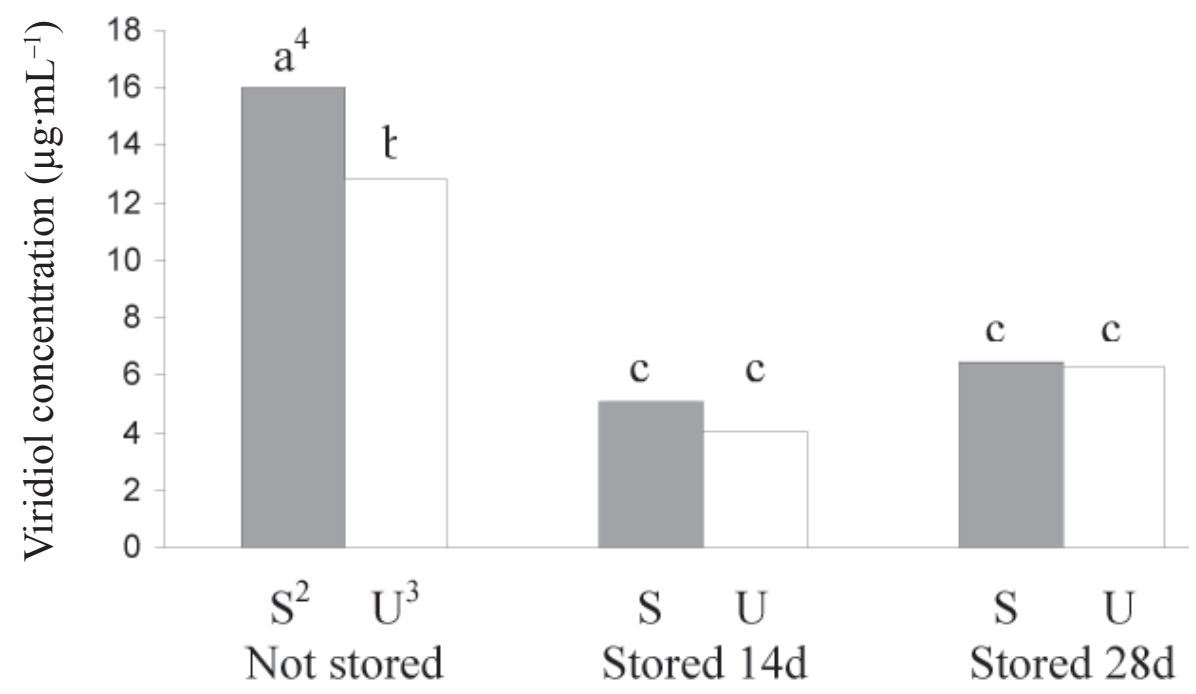

Fig. 1. Concentration of viridiol $\left(\mu \mathrm{g} \cdot \mathrm{mL}^{-1}\right)$ after drying and storage of $T$. virens $+\mathrm{CCM}^{1} .{ }^{1} \mathrm{Cultures}$ prepared by incubation at $25^{\circ} \mathrm{C}$ in the dark for $7 \mathrm{~d}$, air dried for $6 \mathrm{~d}$, sealed and stored. ${ }^{2} \mathrm{CCM}$ originally sterilized before inoculation with $T$. virens. ${ }^{3} \mathrm{CCM}$ originally unsterilized before inoculation with $T$. virens. ${ }^{4} \mathrm{Mean}$ separations by Tukey procedures; values with the same letter are not significantly different at $P \leq 0.05$. tween 7 to $28 \mathrm{~d}$ of incubation. A longer period of incubation $(35 \mathrm{~d})$ resulted in decreased levels of viridiol. (Table 1). Viridiol production was affected by the level of nutrients with which CCM was amended. The concentration of sucrose could be reduced to $167 \mathrm{~g} \cdot \mathrm{kg}^{-1} \mathrm{CCM}$ without loss of viridiol production, however, reduction of the sucrose concentration to 83 $\mathrm{g} \cdot \mathrm{kg}^{-1}$ resulted in a significant reduction in viridiol production (Table 2).

Concentration of viridiol after drying and storage of T. virens $+C C M$. Drying and storage of $T$. virens-incubated CCM resulted in the rapid loss of viridiol, with about $70 \%$ lost within 14 $\mathrm{d}$ of storage. The production of viridiol in $T$. virens + CCM was initially lower in unsterilized CCM than sterilized CCM, but after storage the concentrations of viridiol between unsterilized and sterilized cultures were not significantly different (Fig. 1).

Impact of T. virens $+C C M$ on growth of Amaranthus retroflexus $L$. seedlings in the greenhouse. The application of T. virens $+\mathrm{CMM}$ cultures to pots seeded with $A$. retroflexus in the greenhouse delayed seedling emergence (Table 3). This was true for both 7 and $14 \mathrm{~d}$ CCM cultures of $T$. virens, and was true for both pre-sterilized and unsterilized CCM, and the resulting dry weights of emerged $A$. retroflexus were reduced by all T. virens $+\mathrm{CCM}$ treatments (Table 3).

Impact of $T$. virens $+C C M$ applications upon weed emergence in the field. There was no effect of any treatment on snap bean emergence, stand count or yield (data not shown). The application of $T$. virens $+\mathrm{CCM}$ in the field reduced the emergence of mixed communities of broadleaf weeds relative to the application of uncolonized CCM in both 1997 and 1998, although this effect was not observed for grass weeds (Table 4). The broadleaf community included pigweeds (Amaranthus spp.), common purslane (Portulaca oleracea L.), common lambsquarters (Chenopodium album L.) and eastern black nightshade (Solanum ptycanthum L.). 
Table 3. Impact of Trichoderma virens $+\mathrm{CCM}$ applications upon growth of Amaranthus retroflexus Seedlings in the greenhouse.

\begin{tabular}{lcccc}
\hline & \multicolumn{3}{c}{ No. weeds emerged } & Dry \\
\cline { 2 - 5 } Treatment & $7 \mathrm{DAP}^{\mathrm{z}}$ & $14 \mathrm{DAP}$ & $21 \mathrm{DAP}$ & wt $(\mathrm{g})$ \\
\hline Untreated & $15.9 \mathrm{a}^{\mathrm{y}}$ & $17.8 \mathrm{a}$ & $17.8 \mathrm{a}$ & $0.50 \mathrm{a}$ \\
CCM & $13.3 \mathrm{a}$ & $15.8 \mathrm{a}$ & $17.1 \mathrm{a}$ & $0.37 \mathrm{ab}$ \\
Sterilized (14 d) & $9.7 \mathrm{ab}$ & $15.7 \mathrm{a}$ & $15.8 \mathrm{a}$ & $0.18 \mathrm{bc}$ \\
Unsterilized (14 d) & $6.0 \mathrm{~b}$ & $13.2 \mathrm{a}$ & $13.0 \mathrm{a}$ & $0.18 \mathrm{bc}$ \\
Sterilized (7 d) & $5.8 \mathrm{~b}$ & $12.0 \mathrm{a}$ & $11.6 \mathrm{a}$ & $0.17 \mathrm{bc}$ \\
Unsterilized (7 d) & $4.1 \mathrm{~b}$ & $10.0 \mathrm{a}$ & $8.9 \mathrm{a}$ & $0.09 \mathrm{c}$ \\
\hline
\end{tabular}

${ }^{2} \mathrm{DAP}=$ days after planting.

${ }^{y}$ Mean separations by Tukey procedures; values with the same letter are not significantly different at $P \leq 0.05$.

Table 4. Impact of Trichoderma virens $+\mathrm{CCM}$ applications upon growth of annual broadleaf and grass weeds in the field.

\begin{tabular}{|c|c|c|c|c|}
\hline \multirow[b]{2}{*}{ Treatment } & \multicolumn{2}{|c|}{$\begin{array}{c}\text { Annual broadleaf } \\
\text { weeds } / \mathrm{m}^{2}\end{array}$} & \multicolumn{2}{|c|}{$\begin{array}{l}\text { Annual grass } \\
\text { weeds } / \mathrm{m}^{2}\end{array}$} \\
\hline & 1997 & 1998 & 1997 & 1998 \\
\hline Herbicides & $50 \mathrm{c}^{\mathrm{z}}$ & $139 \mathrm{~b}$ & $0 \mathrm{~b}$ & $25 \mathrm{a}$ \\
\hline $\mathrm{CCM}$ & 249 a & $447 \mathrm{a}$ & $26 \mathrm{a}$ & $34 \mathrm{a}$ \\
\hline T. virens $+\mathrm{CCM}$ & $87 \mathrm{~b}$ & $225 \mathrm{~b}$ & $29 \mathrm{a}$ & $18 \mathrm{a}$ \\
\hline
\end{tabular}

${ }^{2}$ Mean separations by Tukey procedures; values with the same letter are not significantly different at $P \leq 0.05$.

\section{Discussion}

The rapid production, and maintenance for 3 weeks, of high levels of viridiol by $T$. virens grown in CCM, suggests that this system may have potential for preemergence weed control. The biological activity of $T$. virens/CCM cultures was demonstrated both in the greenhouse and the field, where the emergence and development of seedlings of $A$. retroflexus and the emergence of a mixed community of broadleaf weeds were inhibited, respectively.

The effective growth of $T$. virens and production of viridiol was only observed where CCM was amended with large amounts of sucrose. This severely restricts the practical value of the approach due to the prohibitive cost of the sucrose amendment. For CCM to be developed as a practical production and delivery system for $T$. virens, a cost-effective alternative carbon source would be required, and this requirement for nutrient amendments likely represents the most important limitation to the further development of this system for the economic control of weeds. Although highly competitive in the soil environment, $T$. virens populations are not maintained indefinitely at high levels without the provision of supplemental nutrition (Hoitink and Boehm, 1999).

An additional limitation of this system is the short half-life of viridiol in CCM, although the rate of degradation of viridiol may be significantly different under different environmental conditions. The implications of these findings are that deployment of $T$. virens $+\mathrm{CCM}$ would need to be made with fresh-produced material, and that long-term storage should be of fungal cultures rather than the incubated CCM product, presenting a further practical difficulty to the use of $T$. virens as a biological herbicide with a deployment strategy similar to that of conventional herbicides.

These findings demonstrate that a traditional bioherbicide approach is not feasible with this system, but that $T$. virens, produced and deployed in CCM has significant biological activity against weeds, and may have potential in certain carefully targeted applications. It has already been shown that chicken manure and CCM can be suppressive towards plant diseases, and that this activity is mediated primarily following the proliferation of key microbial taxa (Aryantha et al., 2000; Craft and Nelson, 1996; Hoitink and Boehm, 1999; Hoitink and Fahy, 1986; Weller, 1988).

Inoculation of large inoculum doses of $T$. virens into our CCM resulted in its colonization even when it had not been previously sterilized. This raises the possibility that $T$. virens may be grown in situ in very simple systems. Such systems may have potential for weed management in small scale cropping systems, particularly where high value crops are grown, and may have particular potential in vegetable production systems in countries or regions where chemical and mechanical weed management technologies are unavailable. Transplanted crops are likely to be the best target for this technology, since the activity of viridiol is primarily against germinating seeds and seedlings (Hutchinson, 1999; Jones et al., 1988). Transplanted vegetable crops also typically suffer from the lack of effective weed control technologies.

\section{Literature Cited}

Abbas, H.K. and S.O. Duke. 1995. Phytotoxins from plant pathogens as potential herbicides. J Toxicol. Toxin Rev. 14:523-543.

Abbas, H.K., H. Tak, C.D. Boyette, W.T. Shier, and B.B. Jarvis. 2001. Macrocyclic tricothecenes are undetectable in kudzu (Pueraria montana) plants treated with a high-producing isolate of Myrothecium verrucaria. Phytochemistry 58:269-276.

Alstrom, A. and R.G. Burns. 1989. Cyanide production by rhizobacteria as a possible mechanism of plant growth inhibition. Biol. Fert. Soils. 7:232-238.

Amsellem, Z., S. Barghouthi, B. Cohen, Y. Goldwasser, J. Gressel, L. Hornok, Z. Kerenyi, Y. Kleifeld, O. Klein, J. Kroschel, J. Sauerborn, D. Muller-Stover, H. Thomas, M. Vurro, and M.C. Zonno. 2001. Recent advances in the biocontrol of Orobanche (broomrape) species. Biol. Contr. 46:211-228.

Anderson, K.I. and S.G. Hallett. 2004. Herbicidal spectrum and activity of Myrothecium verrucaria. Weed Sci. 52:623-627.

Aryantha, I.P., R. Cross, and D.I. Guest. 2000. Suppression of Phytophthora cinnamomi in potting mixes amended with uncomposted and composted animal manures. Phytopathology 90:775-782.

Bolton, H. and L.F. Elliot. 1989. Toxin production by a rhizobacterial Pseudomonas spp. that inhibits wheat growth. Plant Soil 114:269-278.

Boyetchko, S.M. 1996. Impact of soil microorganisms on weed biology and ecology. Phytoprotection 77:41-56.

Boyette, C.D., P.C. Quimby, A.J. Caesar, J.L. Birdsall, W.J. Connick, D.J. Daigle, M.A. Jackson, G.H. Egley, and H.K. Abbas. 1996. Adjuvants, formulations, and spraying systems for imporvement of mycoherbicides. Weed Technol. 10:637-644.

Boyette, CD, HL Walker, and HK Abbas. 2002. Biological control of kudzu (Puereria montana) with an isolate of Myrothecium verrucaria. Biol. Contr. Sci. Technol. 12:75-82.

Brière, S.C., A.K. Watson, T.C. Paulitz, and S.G. Hallett. 2000. Oxalic acid production and mycelial biomass yield of Sclerotinia minor for the formulation enhancement of a granular turf bioherbicide. Biol. Contr. Sci. Technol. 10:281-289.

Charudattan, R. 2001. Biological control of weeds by means of plant pathogens: Significance for integrated weed management in modern agroecology. Biol. Contr. 46:229-260.

Cherrington, C.A. and L.F. Elliott. 1987. Incidence of inhibitory pseudomonads in the Pacific Northwest. Plant Soil 101:159-165.

Ciotola, M., A.K. Watson, and S.G. Hallett. 1996. Discovery of an isolate of Fusarium oxysporum with potential to control Striga hermonthica in Africa. Weed Res. 35:303-309.

Craft, C.M. and E.B. Nelson. 1996. Microbial properties of composts that suppress dampingoff and root rot of creeping bentgrass caused by Pythium graminicola. Appl. Environ. Microbiol. 62:1550-1557.

Daigle, D.J., W.J. Connick, C.D. Boyette, M.P. Lovisa, K.S. Williams, and M. Watson. 1997. Twin-screw extrusion of 'Pesta'-encapsulated biocontrol agents. World J. Microbiol. Biotechnol. 13:671-676.

Eyal, J., C.P. Baker, J.D. Reeder, W.E. Devane, and R.D. Lumsden. 1997. Large-scale production of chlamydospores of Gliocladium virens strain GL-21 in submerged culture. J. Ind. Microbiol. Biotechnol. 19:163-168.

Foster, R., R.X. Latin, E. Maynard, R. Weinzeirl, D. Eastburn, H. Taber, B. Barrett, and B. Hutchison. 1998. ID-56 Midwest vegetable production guide 1998 for commercial growers. Coop. Ext. Serv. Purdue Univ., West Lafayette, Ind.

Gomez, K.A. and A.A. Gomez. 1984. Statistical procedures for agricultural research. 2nd ed. Wiley, New York.

Hallett, S.G. 2005. Where are the bioherbicides? Weed Sci. (in press).

Harman, G.E. 1992. Development and benefits of rhizosphere competent fungi for biological control of plant pathogens. J. Plant Nutr. $15: 835-843$

Héraux, F.M.G. 1999. Evaluation of composted chicken manure as a growth and delivery substrate for the biological weed control agent Gliocladium virens in sustainable vegetable production. MS thesis. Purdue Univ., West Lafayette, Ind.

Hoitink, H.A.J. and M.J. Boehm. 1999. Biocontrol within the context of soil microbial communities: Asubstrate-dependent phenomenon. Annu. Rev. 
Phytopathol. 37:427-446.

Hoitink, H.A.J. and P.C. Fahy. 1986. Basis for the control of soilborne plant pathogens with composts. Annu. Rev. Phytopathol. 24:93-114.

Howell, C.R. and R.D. Stipanovic, 1984.Phytotoxicity to crop plants and herbicidal effects on weeds of viridiol produced by Gliocladium virens. Phytopathology 74:1346-1349.

Hutchinson, C.M. 1997. Annual rye (Cereale secale) and Gliocladium virens inoculated composted chicken manure as weed control options in horticultural production. $\mathrm{PhD}$ thesis. Purdue Univ., West Lafayette, Ind.

Hutchinson, C.M. 1999. Trichoderma virens-inoculated composted chicken manure for biological weed control. Biol. Contr. 16:217-222.
Jones, R.W. and J.G. Hancock. 1987. Conversion of viridin to viridiol by viridian-producing fungi. Can. J. Microbiol. 33:963-966.

Jones, R.W., W.T. Lanini, and J.G. Hancock. 1988. Plant growth response to the phytotoxin viridiol produced by the fungus Gliocladium virens. Weed Sci. 36:683-687.

Kelleher, B.P., J.J. Leahy, A.M. Henihan, T.F. O'Dwyer, D. Sutton, and M.J. Leahy. 2002. Advances in poultry litter disposal techniques-A review. Bioresource Technol. 83:27-36.

Kremer, R.J., M.F.T. Begonia, L. Stanley, and E.T. Lanham. 1990. Characterization of rhizobacteria associated with weed seedlings. Appl. Environ. Microbiol. 56:1649-1655.

Kremer, R.J. and A.C. Kennedy. 1996. Rhizobacteria as biocontrol agents of weeds. Weed Technol.
10:601-609.

Sarwar, M. and R.J. Kremer. 1995. Enhanced suppression of plant growth through production of L-tryptophan-derived compounds by deleterious rhizobacteria. Plant Soil 172:261-269.

Vogelgsang, S., A.K. Watson, and A. DiTommaso. 1998. Effect of soil incorporation and dose on control of field bindweed (Convolvulus arvensis) with the pre-emergence bioherbicide Phomopsis convolvulus. Weed Sci. 46:690-697.

Walker, H.L. and A.M. Tilley. 1997. Evaluation of an isolate of Myrothecium verrucaria from sicklepod (Senna obtusifolia) as a potential mycoherbicide agent. Biol. Contr. 10:104-112.

Weller, D.M. 1988. Biological control of soilborne plant pathogens in the rhizosphere with bacteria. Annu. Rev. Phytopathol. 26:379-407. 